\title{
Systemic Ozone Therapy by Rectal Insufflation for Immunoglobulin A Deficiency
}

\author{
Jacqueline Díaz-Luis MD MS, Silvia Menéndez-Cepero PhD, Consuelo Macías-Abraham MD PhD, Lucía Fariñas-Rodríguez MS
}

\begin{abstract}
SUMMARY
INTRODUCTION IgA deficiency is a primary immunodeficiency predominantly due to an antibody defect, for which there is no replacement therapy. Treatment consists of prevention and treatment of infections and other associated conditions. Given the immunomodulatory and regulatory properties of the redox balance of ozone therapy in infectious and inflammatory conditions, evaluation of its effect on IgA deficiency is of interest.
\end{abstract}

OBJECTIVE Assess the benefits and possible adverse effects of ozone treatment in patients with IgA deficiency.

METHODS A monocentric randomized controlled phase 2 clinical trial (RPCEC 00000236) was carried out, after approval by the Institutional Ethics Committee of the Roberto Rodríguez Fernández Provincial General Teaching Hospital in Morón, Ciego de Ávila Province, Cuba. Included were 40 patients aged 5-50 years, distributed in 2 groups of 20 , after agreeing to participate and signing informed consent. The experimental group received 2 cycles of ozone by rectal insufflation for 20 days ( 5 times a week for 4 weeks each cycle) with a 3-month interval between cycles, for a total of 40 doses, with age-adjusted dose ranges. The control group was treated with leukocyte transfer factor (Hebertrans), $1 \cup$ per $\mathrm{m}^{2}$ of body surface area subcutaneously, once weekly for 12 weeks. Frequency of appearance and severity of clinical symptoms and signs of associated diseases, serum immunoglobulin concentrations and balance of pro-oxidant and antioxidant biomarkers were recorded at treatment initiation and one month after treatment completion. Therapeutic response was defined as complete, partial, stable disease or progressive disease. Descriptive statistics and significance were calculated to compare groups and assess effect size.

RESULTS One month after treatment completion, $70 \%$ of patients in the experimental group experienced significant increases in $\lg G$ $(p=0.000)$ and $\operatorname{lgM}(p=0.033)$. The experimental group also displayed decreased pro-oxidation biomarkers, glutathione modulation and increased antioxidant enzymes, with reduced oxidative stress; none of these occurred in the control group. Complete therapeutic response was achieved in $85 \%$ of patients in the experimental group and only $45 \%$ in the control group. Mild, transient adverse events were reported in both groups.

CONCLUSIONS Ozone therapy by rectal insufflation is a suitable therapeutic option for treating $\lg \mathrm{A}$ deficiency because it produces antioxidant and immunomodulatory effects and is feasible, safe and minimally invasive.

KEYWORDS Ozone therapy, IgA deficiency, primary immunodeficiency, oxidative stress, antioxidants, pro-oxidants, Cuba

CONTRIBUTION OF THIS RESEARCH This paper introduces in Cuba a new treatment a for IgA deficiency, with immunomodulatory and antioxidant effects offering substantial clinical benefits to patients with this immunodeficiency.

\section{INTRODUCTION}

Primary or inherited immunodeficiencies (PIDD) are infrequent. Their prevalence varies by type of genetic defect; while selective IgA deficiency is relatively common, more serious defects such as severe combined immunodeficiency are rare. New immunodeficiencies are continually being discovered, so the exact prevalence is unknown, although considered to be low.[1] In Cuba these diseases are underreported because of lack of specific diagnosis, among other causes.[2] The global incidence of IgA deficiency varies by ethnic origin. In the USA, estimated PIDD frequency varies between 1:1000 and 1:223 in the general population, and is much lower, between 1:18,000 and 1:2600 in those of Asian origin.[3]

According to criteria of the Pan American Immunodeficiency Group and the European Immunodeficiency Society, two clinical forms of IgA deficiency-complete and partial deficits-are included as PIDDs "predominantly due to antibody defect" and may be associated with failure in formation of antibodies against polysaccharide antigens or deficiencies of IgG2. When secretory IgA is lacking, patients may remain asymptomatic $(70 \%$ of those affected) or develop florid clinical presentations in which infectious, allergic and autoimmune diseases predominate.[3,4]

IgA deficiency was the most frequent PIDD among patients with suspected immunodeficiencies seen at the Ciego de Ávila provincial Immunology Service during the six years of this study (1 of every 101). Thus, PIDD is considered an important health problem for immunology and allergology services in the province. Other PIDDs were less frequent, 1 of every 509 seen (administrative data, Immunology Service, Roberto Rodríguez Fernández Provincial General Teaching Hospital).

Recurrent bacterial respiratory infections are the most common health problem in patients with IgA deficiency; some can also develop gastrointestinal parasitic infections, such as giardiasis, and allergic and autoimmune disorders. An association between IgA deficiency and bronchial asthma is also reported.[3-6]

IgA deficiency has no specific or replacement treatment. Infections are treated with antimicrobials depending on the sensitivity of the causal agent. Some patients need prolonged antibiotic prophylaxis against infections to avoid complications. When allergic and autoimmune diseases coincide with IgA deficiency, specific treatment for each disease is used. A therapeutic alternative could be replacement or supply of external sources of IgA, but blood products that contain it (human immunoglobulin preparations) are not recommended, due to risk of anaphylactic reactions in patients with anti-IgA antibodies.[7,8] These treatment limitations led to a search for effective and noninvasive options to improve patients' immune response, particularly against infections.

The normal immune response involves cellular receptors, costimulatory signals, cytokines and regulation by oxidation- 
reduction (redox) processes.[9] In recurrent infections, as well as allergic and autoimmune diseases, the balance between free oxygen radical production and antioxidant systems is tilted in favor of the former, causing oxidative damage to proteins, lipids, DNA, organs and systems. Reversing the effects of free radicals and regulating the redox state requires safe and effective therapeutic interventions; ozone has been suggested as an appropriate treatment.[10,11]

Ozone's immune system effects have been described by Bocci and Larini.[10,12] Ozone is a prodrug with oxidizing properties, which produces biological effects in the body with a biphasic dose response (hormesis). Therapy is based on reversion of chronic oxidative stress at the cellular level and modulating effects on immune system function.[10]

In Cuba, ozone has had beneficial effects in management of various secondary humoral and cellular immune deficiencies, including HIVIAIDS, autoimmune diseases such as rheumatoid arthritis, and phagocytic immunodeficiencies.[13-15] Several studies show the immunomodulatory, antioxidant and antiinflammatory effects of ozone therapy.[13-16]

IgA-deficient patients in Cuba may benefit from the demonstrated utility of ozone therapy for treatment of various conditions, its safety and well-understood main mechanisms, if used under internationally recommended good practice standards.[17] This therapy may successfully treat conditions caused by the underlying disorder and accompanying diseases, both infectious and due to immune system deregulation. We therefore proposed evaluating the potential benefits and adverse effects of ozone treatment in such patients.

\section{METHODS}

A monocentric, randomized, controlled, phase 2, open-label clinical trial (RPCEC 00000236) was carried out. Participation criteria were defined: inclusion (age 5-50 years, either sex, complete or partial IgA deficiency, selective or with deficient response of specific antibodies, isolated or associated with allergic or autoimmune diseases); exclusion (blood transfusions three months before or during the trial, any immunomodulatory treatment within the previous 6 months); and withdrawal (serious adverse reactions; treatment noncompliance or abandonment). Needed statistical power was calculated, considering prevalence variability and acceptable type 1 error.

The study population comprised 40 patients, aged 5-50 years, of both sexes, seen in the Immunology Service from January 18, 2010 through September 12, 2016. There were no withdrawals. Adults provided written informed consent to participate in the trial; parents gave written concent for participating children.

Patients were assigned by systematic random sampling to two groups, experimental (EG) and control (CG), 20 cases each. Members of both groups received specific treatment for their allergic disorder or autoimmune disease.

Treatment The EG received two cycles of ozone therapy by rectal insufflation. Each cycle consisted of 20 sessions ( 5 per week), with a 3-month interval between cycles. Ozone was produced by an ozone generator (OZOMED plus, Havana, Cuba). Recommended age-specific doses were applied according to the following schedule.[18]

- 5-10 years: $1.25-3 \mathrm{mg}$ (25 mg/L concentration in $50 \mathrm{~mL}$ to 30 $\mathrm{mg} / \mathrm{L}$ in $100 \mathrm{~mL}$ )

- $11-15$ years: $2.25-4.2 \mathrm{mg}$ (30 mg/L in $75 \mathrm{~mL}$ to $35 \mathrm{mg} / \mathrm{L}$ in 120 $\mathrm{mL})$

- >15-50 years: $2-8 \mathrm{mg} \mathrm{(20} \mathrm{mg/L} \mathrm{in} 100 \mathrm{~mL}$ to $40 \mathrm{mg} / \mathrm{L}$ in 200 $\mathrm{mL})$

The CG received Hebertrans transference factor (Genetic Engineering and Biotechnology Center, Cuba). Dosage was one unit per $\mathrm{m}^{2}$ of body surface subcutaneously, once weekly for 12 weeks.[19]

Variables Therapeutic response was assessed as complete, partial, stable disease and progressive disease.

- Complete: satisfactory clinical status (absence of infectious diseases characteristic of these patients), increased IgM or lgG; normalization of all pro-oxidant parameters and increase of $\geq 2$ antioxidant parameters

- Partial: satisfactory or acceptable clinical status (absence or decrease in severity and frequency of infectious diseases characteristic of these patients), increased IgM or lgG, normalization of $\geq 1$ pro-oxidant parameter and increase of $\geq 1$ antioxidant parameter

- Stable disease: presenting one or two of the following-clinical status the same as at onset, no increased IgM or lgG, no normalization of pro-oxidant parameters, and no activation of antioxidant parameters

- Progressive disease: with three or four of the followingworsening clinical condition, no increased $\lg M$ or $\operatorname{lgG}$, no normalization of pro-oxidant parameters and no activation of antioxidant parameter

Serum was obtained by centrifugation and decantation after clot retraction, and simple radial immunodiffusion was used for immunoglobulin quantification, results expressed in $\mathrm{mg} / \mathrm{mL}$. Specific antibodies against tetanus and diphtheria toxoids were determined by ELISA, results expressed in $\mathrm{IU} / \mathrm{mL}$. Absolute values of lymphoid populations were estimated by flow cytometry. $[20,21]$

Plasma was obtained to assess redox state biomarkers, using EDTA as anticoagulant and erythrocyte lysate.

Pro-oxidation biomarkers: Concentration of malondialdehyde (MDA), a lipid peroxidation marker, was determined in plasma by the method described in LPO-586TM of the BIOXYTECH assay (OXIS Indague, USA), values expressed in $\mu \mathrm{mol} / \mathrm{L}$.[22] Advanced oxidation protein products (AOPP) were evaluated by Witko's spectrophotometric technique, values expressed in $\mu \mathrm{mol} / \mathrm{L} .[23]$ A colorimetric method was used for total peroxide quantification, based on oxidation of ferrous to ferric ions mediated by hydrogen peroxide $\left(\mathrm{H}_{2} \mathrm{O}_{2}\right)$ under acidic conditions, results expressed in $\mu \mathrm{mol} / \mathrm{L} .[24]$

Biomarkers of antioxidant defense: Superoxide dismutase activity was determined by Marklund's indirect kinetic method,[25] results expressed in percentage inhibition/minute/mL of enzyme $(\mathrm{U} / \mathrm{mL})$. Erythrocyte catalase activity was determined by a direct kinetic method using $\mathrm{H}_{2} \mathrm{O}_{2}$ as substrate, results expressed in $\mathrm{mmol}$ 
$\mathrm{H}_{2} \mathrm{O}_{2} / \mathrm{t} / \mathrm{min} / \mathrm{mL}$.[26] Cellular glutathione peroxidase activity was determined by Paglia and Valentine's technique, units of enzymatic activity expressed in $\mathrm{mU} / \mathrm{mL}$.[27] Plasma concentration of protein thiols, referred to as reduced glutathione, was determined by Sedlak and Lindsay's technique, results expressed in $\mu \mathrm{mol} / \mathrm{L}$. [28] Total antioxidant capacity of plasma was measured by the ferric-reducing plasma ability assay, an indicator of antioxidant power and plasma ability to reduce ferric ions to ferrous, results expressed in $\mathrm{mM} \mathrm{Fe}^{2+} / \mathrm{L}$.[29]

Data collection and management Information was collected in patient registers and data collection notebooks.

Analysis Simple descriptive statistics demonstrated group homogeneity of demographic, clinical and immunological factors. The dependent-samples $T$ test was used to compare groups with respect to response variables, comparing before and after treatment values in each group, and changes between groups by the double difference method. SPSS version 15.0 was used for analysis. The threshold specified for statistical significance was $p \leq 0.05$.

Ethics Safety-related variables were analyzed as stipulated by the National Drug and Medical Equipment Quality Control Center (CECMED) in Regulation No. 45-2007 for notification and reporting of serious or unexpected adverse events in clinical trials.[30] Adult participants and children's parents or legal guardians were given a detailed explanation of the trial, treatments used, and informed that they would receive one of two therapeutic options, both of which were expected to provide benefits by improving or temporarily eliminating some clinical manifestations of disease; $[10,12-19]$ that allocation would be randomized, to avoid subjectivity; and that participants could abandon the trial at will, without prejudice to care. The trial was approved by the Research Ethics Committee of the Roberto Rodríguez Fernández Provincial General Teaching Hospital (main sponsor) and complied with the principles of the Helsinki Declaration.[31]

\section{RESULTS}

At trial onset, the groups were homogeneous with respect to demographic, clinical and immunological factors. Most patients were aged $5-10$ years (14 cases in the EG and 16 in the CG) and male sex predominated (Table 1). Susceptibility to infection was evidenced by history of recurrent bacterial respiratory infections (3 events in one year and inadequate response to antibiotics) in 33 cases (18 in the EG and 15 in the CG) (82.5\% of total) and by infectious parasitic diseases such as giardiasis in 17 patients (42.5\% of total, 8 in the CG and 9 in the EG). Among concurrent diseases, allergy ranked first (32 cases, $80 \%$ ) and of these, bronchial asthma was the most frequent with 25 cases $(62.5 \%$ of total, 14 in the EG and 11 in the CG). Autoimmune diseases were diagnosed in 2 patients, one with rheumatoid arthritis (EG) and another with vitiligo (CG).

Immunological alterations were detected at trial onset, including decreased antibodies against protein antigens of tetanus and diphtheria toxoids in 2 patients, with values lower than those considered protective for these diseases $(>0.1 \mathrm{IU} / \mathrm{mL})$ and below-normal CD19+ B cell levels (>1\%) in 10 cases. According to these results for immunological parameters, 95\% (38/40) of cases showed selective $\lg A$ deficiency and $5 \%(2 / 40) \lg A$ deficiency associated with functional response deficit (Table 1).
At treatment completion, complete $\lg$ A deficiency (IgA values below $0.07 \mathrm{~g} / \mathrm{L})$ was found in 10 cases $(25 \%)$ and partial $(\lg A$ values at least 2 standard deviations below normal values for age) in $30(75 \%)$; IgM and IgG were normal in these cases at onset. After two cycles of ozone therapy, significant differences were observed between the EG and CG in $\lg G(p=0.000)$ and $\lg M$ $(p=0.033)$ (Table 2).

The results of the oxidative stress study (Table 3), showed imbalances in the redox system with respect to normal reference values, since AOPP and MDA were elevated at study onset in both groups, indicating that patients with IgA deficiency had a prooxidant redox state. Reduced glutathione was elevated in $80 \%$ of patients and glutathione peroxidase was $60 \%$ below reference values for healthy individuals.

After two cycles of ozone therapy, AOPP $(p=0.003)$ and MDA $(p=0.001)$ decreased. Levels of total peroxides did not vary, and reduced glutathione was normalized $(p=0.032)$. Redox

Table 1: Demographic and clinical characteristics of IgA-deficient individuals

\begin{tabular}{|c|c|c|c|}
\hline \multicolumn{2}{|c|}{ Characteristics } & $\begin{array}{c}\text { Experimental } \\
\text { group } \\
n=20 \\
n(\%)\end{array}$ & $\begin{array}{l}\text { Control } \\
\text { group } \\
n=20 \\
n(\%)\end{array}$ \\
\hline \multirow{2}{*}{ Age } & $5-10$ & $14(70)$ & $16(80)$ \\
\hline & $11-15$ & $6(30)$ & $4(20)$ \\
\hline \multirow{2}{*}{ Sex } & Female & $7(35)$ & $8(40)$ \\
\hline & Male & $13(65)$ & $12(60)$ \\
\hline \multirow{2}{*}{$\begin{array}{l}\text { Clinical } \\
\text { presentation }\end{array}$} & $\begin{array}{l}\text { Recurrent respiratory } \\
\text { infection }\end{array}$ & $18(90)$ & $15(75)$ \\
\hline & Giardiasis & $8(40)$ & $9(45)$ \\
\hline \multirow{4}{*}{$\begin{array}{l}\text { Associated } \\
\text { diseases }\end{array}$} & Bronchial asthma & $14(70)$ & $11(55)$ \\
\hline & Atopic dermatitis & $2(10)$ & $3(15)$ \\
\hline & Allergic rhinitis & $1(5)$ & $1(5)$ \\
\hline & Autoimmune disease & $1(5)$ & $1(5)$ \\
\hline \multirow{3}{*}{$\begin{array}{l}\text { Immunological } \\
\text { abnormalities }\end{array}$} & Selective $\lg A D$ & $14(70)$ & $16(80)$ \\
\hline & $\begin{array}{l}\text { IgAD with decreased } \\
\text { CD19+ a }\end{array}$ & $6(30)$ & $4(20)$ \\
\hline & $\begin{array}{l}\text { Anti-TT and -TD } \\
\text { decreased }^{b}\end{array}$ & $1(5)$ & $1(5)$ \\
\hline
\end{tabular}

anormal $>1 \%$ bnormal $>0.1 \mathrm{IU} / \mathrm{mL}$

CD19+: B-lymphocyte positive for CD19 antigen IgAD: IgA deficiency anti-TD: diphtheria toxoid antibody anti-TT: tetanus toxoid antibody

Table 2: Immunoglobulin levels in IgA-deficient individuals treated with ozone or Hebertrans

\begin{tabular}{|c|c|c|c|c|c|}
\hline & \multicolumn{2}{|c|}{$\begin{array}{c}\text { Experimental group } \\
\text { (ozone therapy) } \\
n=20 \\
\text { mean (SD) }\end{array}$} & \multicolumn{2}{|c|}{$\begin{array}{c}\text { Control group } \\
\text { (Hebertrans) } \\
n=20 \\
\text { mean (SD) }\end{array}$} & \multirow[t]{2}{*}{ p Value ${ }^{a}$} \\
\hline & Initial & After 1 month & Initial & After 1 month & \\
\hline $\lg G(g / L)$ & $\begin{array}{r}8.2 \\
(1.1)\end{array}$ & $\begin{array}{r}12.0 \\
(0.8)^{\mathrm{b}}\end{array}$ & $\begin{array}{r}9.2 \\
(0.80)\end{array}$ & $\begin{array}{r}9.1 \\
(0.98)^{\mathrm{b}}\end{array}$ & 0.000 \\
\hline $\lg A(g / L)$ & $\begin{array}{r}0.07 \\
(0.01)\end{array}$ & $\begin{array}{r}0.12 \\
(0.02)\end{array}$ & $\begin{array}{r}0.08 \\
(0.01)\end{array}$ & $\begin{array}{r}0.09 \\
(0.02)\end{array}$ & NS \\
\hline $\lg M(g / L)$ & $\begin{array}{r}1.2 \\
(0.2)\end{array}$ & $\begin{array}{r}1.9 \\
(0.39)^{\mathrm{b}}\end{array}$ & $\begin{array}{r}1.5 \\
(1.10)\end{array}$ & $\begin{array}{r}1.6 \\
(0.32)^{b}\end{array}$ & 0.033 \\
\hline
\end{tabular}

aassociated with double difference

${ }^{\mathrm{b}}$ significant differences between values before and after treatment NS: not significant 
Table 3: Pro-oxidant and antioxidant biomarkers in IgA-deficient individuals before and after treatment

\begin{tabular}{|c|c|c|c|c|c|}
\hline \multirow[t]{2}{*}{ Biomarkers } & \multicolumn{2}{|c|}{$\begin{array}{c}\text { Experimental group } \\
n=20 \\
\text { mean (SD) }\end{array}$} & \multicolumn{2}{|c|}{$\begin{array}{c}\text { Control group } \\
n=20 \\
\text { mean (SD) }\end{array}$} & \multirow[t]{2}{*}{ value $^{\mathbf{p}}$} \\
\hline & Initial & Final & Initial & Final & \\
\hline MDA ( $\mu \mathrm{mol} / \mathrm{L})$ & $\begin{array}{r}1.98 \\
(1.70)\end{array}$ & $\begin{array}{r}0.77 \\
(0.11)^{b}\end{array}$ & $\begin{array}{r}1.86 \\
(1.41)\end{array}$ & $\begin{array}{r}1.20 \\
(0.27)^{\mathrm{b}}\end{array}$ & 0.001 \\
\hline AOPP $(\mu \mathrm{mol} / \mathrm{L})$ & $\begin{array}{l}55.88 \\
(1.36)\end{array}$ & $\begin{array}{r}41.20 \\
(1.72)^{b}\end{array}$ & $\begin{array}{l}53.90 \\
(1.29)\end{array}$ & $\begin{array}{r}50.48 \\
(0.55)^{b}\end{array}$ & 0.003 \\
\hline FOX ( $\mu \mathrm{mol} / \mathrm{L})$ & $<1$ & 1.1 & $<1$ & $<1$ & NS \\
\hline $\mathrm{SOD}(\mathrm{U} / \mathrm{mL})$ & $\begin{array}{r}154.23 \\
(10.02)\end{array}$ & $\begin{array}{l}176.20 \\
(3.20)^{b}\end{array}$ & $\begin{array}{r}158.59 \\
(9.10)\end{array}$ & $\begin{array}{l}159.09 \\
(2.12)^{b}\end{array}$ & 0.001 \\
\hline CAT (U/mL) & $\begin{array}{l}70.88 \\
(4.20)\end{array}$ & $\begin{array}{r}78.14 \\
(1.10)\end{array}$ & $\begin{array}{l}67.61 \\
(3.10)\end{array}$ & $\begin{array}{r}78.58 \\
(1.40)\end{array}$ & NS \\
\hline GSH $(\mu \mathrm{mol} / \mathrm{L})$ & $\begin{array}{r}42.12 \\
(1.14)\end{array}$ & $\begin{array}{r}35.02 \\
(1.12)^{b}\end{array}$ & $\begin{array}{l}40.06 \\
(2.02)\end{array}$ & $\begin{array}{r}40.09 \\
(1.02)^{b}\end{array}$ & 0.032 \\
\hline $\mathrm{GPx}(\mathrm{mU} / \mathrm{mL})$ & $\begin{array}{r}28,436.43 \\
(346.65)\end{array}$ & $\begin{array}{r}33,874.40 \\
(134.08)^{b}\end{array}$ & $\begin{array}{r}27,913.09 \\
(450.12)\end{array}$ & $\begin{array}{r}27,073.34 \\
(250.12)^{b}\end{array}$ & 0.012 \\
\hline $\mathrm{FRAP}\left(\mathrm{mM} \mathrm{Fe}^{2+} / \mathrm{L}\right)$ & $\begin{array}{r}0.16 \\
(0.03)\end{array}$ & $\begin{array}{r}0.27 \\
(0.09)^{b}\end{array}$ & $\begin{array}{r}0.18 \\
(0.02)\end{array}$ & $\begin{array}{r}0.19 \\
(0.03)^{b}\end{array}$ & 0.001 \\
\hline
\end{tabular}

aassociated with double difference

'significant differences between values before and after treatment

AOPP: advanced oxidation protein products CAT: catalase

FOX: total peroxides FRAP: ferric reducing antioxidant power

GSH: reduced glutathione GPx: glutathione peroxidase

MDA: malondialdehyde SOD: superoxide dismutase

NS: not significant

balance was favored in the EG, since significant increases were found in several antioxidant defense markers, such as superoxide dismutase $(p=0.001)$, cellular glutathione peroxidase $(p=0.012)$ and ferric reducing ability of plasma $(p=0.001)$ (Table 3 ). Increased antioxidants and decreased pro-oxidants were not found in the CG.

Therapeutic response was complete in $85 \%(17 / 20)$ of the EG, and partial in $15 \%(3 / 20)$. Complete response was found in $45 \%$ $(9 / 20)$ of the CG, partial in $35 \%(7 / 20)$; disease was stable in $20 \%$ (4/20). Adverse events in the EG were mild and transient, and included tympanites immediately after rectal insufflation in two patients and abdominal pain in one. In the CG, erythema and pain at the injection site were reported by 8 patients (40\%).

\section{DISCUSSION}

Some authors consider that IgA deficiency can be diagnosed in young children, since the majority of patients, who have $\lg A$ below $0.07 \mathrm{~g} / \mathrm{L}$ at age 3 years $(77 \%)$ are still $\mathrm{IgA}$ deficient at age 7 years.[4,8] However, since it could be confused with transient immunodeficiency of childhood, which occurs in young children due to delay in immune system development after birth,[3] we hold that age is an essential criterion for diagnosis, and that diagnosis of IgA deficiency should be made after the age of possible confusion with transient immunodeficiency of childhood; hence the lower limit in our study population.

The presence of recurrent respiratory and digestive infectious diseases is consistent with that reported by Domínguez in a chart review of 330 patients with IgA deficiency[32] and De Oliveira in a review of 39 patient files.[33] IgA deficiency manifests more frequently as digestive and respiratory system infections, as in the study cases, because IgA is predominant in mucosal secretions. IgA has an important biological function in mucous tissues, since it can neutralize viruses, bind to toxins, agglutinate bacteria, prevent bacteria from binding to epithelial cells and inhibit absorption of food antigens, thus preventing their entry into the bloodstream. These functions explain why lgA deficiency leads to a more aggressive bacterial microbiota and predisposes to local inflammatory processes. It has been suggested that low serum IgA levels cause less IgA transport to mucosal surfaces.[9] As in other studies, we found partial IgA deficiency was more frequent than complete deficiency.[32,33]

IgA deficiency is associated with a high prevalence of allergies, as found in our study, in which $80 \%$ of patients had clinical manifestations of these diseases. The literature reports that allergic disorders may be the initial clinical manifestation.[33,34] This may be because lack or insufficient concentrations of IgA causes partial loss of ability to block allergen entry through the mucosa, which induces sensitization and predisposes to development of allergies. Although the mechanism for association between bronchial asthma and IgA deficiency is unknown, some genetic defects, such as TNFRSF3B variants, may increase risk of this disease.[34]

Basal serum concentrations of specific antibodies prevaccination may be protective and are therefore valuable for studying humoral immunocompetence in IgA deficiency, since the humoral component of the immune response is compromised. The decreased $B$ lymphocyte population in 10 patients is consistent with the findings of a Brazilian study.[35] Some studies show decreased $\mathrm{CD}^{+} \mathrm{T}$ lymphocytes in IgA-deficient patients.[36,37] Existence of an associated immune defect indicates that patients require more effective monitoring. It is important to study cell markers and activation in these patients, since IgA deficiency can progress to a common variable immunodeficiency.

Due to lack of specific treatment for IgA deficiency in Cuba, it is treated with Hebertrans because of its favorable clinical effects and immunomodulatory actions (expressed by an antigen-dependent and specific late cutaneous hypersensitivity reaction, in addition to other effects related to cell-mediated immunity).[38,39] Taking into account published evidence of these effects, Hebertrans was administered to the control group to comply with the ethical imperative of using the best available product comparable to the one being tested.

According to Viebahn-Hänsler, ozone requires systemic application to achieve good immunomodulation results. Rectal insufflation has been reported to have a systemic effect similar to major autohemotherapy in $90 \%$ of patients and it is the route of choice in children, older adults and patients who cannot tolerate intravenous therapies.[18] The biological effect of rectal ozone insufflation pathway has been demonstrated in preclinical models and clinical research.[40]

The significant increases in IgG and IgM after two cycles of ozone therapy show the effect of ozone on these immunological parameters, favorably impacting clinical status of patients who had good therapeutic response by decreasing infection recurrence. This result is based on the role of immunoglobulins in the humoral response of adaptive immunity; their functional integrity is essential to maintain immune system homeostasis. Various studies demonstrate the immunomodulatory effect of ozone therapy on antibody response and other immunological parameters.[15,41-43] 
The fact that in this series of patients, AOPP and MDA were high in the initial assessment reveals the predominance of prooxidant damage. This is probably a consequence of intense and sustained activation of oxidative enzymes during recurrent infections and inflammatory processes, causing an excess of free radicals surpassing the capacity of endogenous antioxidant systems, with subsequent damage to proteins and lipids. The effect of free radicals on lipids is known as lipid peroxidation, and leads to destruction of the original lipid and loss of membrane integrity. MDA is a marker of this process. The effect on proteins causes amino acid oxidation, cross-linking of peptide chains and formation of carbonyl groups, evidenced by AOPP elevation.[44] From these results presence of inflammatory type oxidative stress can be inferred, caused by excessive activation of the natural mechanisms that generate reactive species and are associated with greater activation of the enzyme NADPH oxidase involved in chronic inflammation.[44]

The increase in pro-oxidant parameters and consequent oxidative stress is highly relevant to health-disease mechanisms, since it is associated with various pathological processes; in immunodeficiencies, it causes immune system dysfunction, which worsens existing deficits.[44-46] Immune system functioning is strongly influenced by redox balance, particularly in cells that have cytotoxic and phagocytic functions, which, due to their microbicidal activity are connected to free radical generation and deteriorate under oxidative stress. In IgA deficiency, other associated conditions, such as allergies and autoimmunity, worsen redox balance, resulting in tissue damage by free radicals. The pathophysiological repercussions of oxidation in IgA-deficient patients with allergies or autoimmunity are further immune dysfunction and lower response to immunomodulatory treatments. $[15,47]$

The significant increase in antioxidant parameters and decrease in pro-oxidants after two cycles of ozone therapy in the EG compared to the $C G$ is a consequence of oxidative preconditioning, which ensures that a cycle of 20 ozone treatments is enough to maintain the positive effect for approximately 3 months, depending on the disease and patient response.[40]

The importance of this result is that the increase in antioxidant enzymes prevents free radicals from damaging vital structures and halts production of new oxidant molecules. As cells shift from an oxidizing to a reducing environment, they maintain membrain integrity and retain their specific functions, which, in the case of immune system cells, is defense against pathogenic microorganisms.[48]

The mechanism of ozone therapy's antioxidant action at controlled doses is based on its ability to act as a hormetic stressor, which activates the related erythroid nuclear factor 2, Nrf2, in cytoplasm. When released from the adapter protein Keap1, this transcription factor binds to the DNA regions that regulate antioxidant response, increasing expression of genes involved in this defense. In an in vitro assay, Bocci identified several transcription factors in peripheral blood cells activated by ozone, such as: Nrf2, NFAT, AP-1 protein, and NF-Kappa B. Activation of Nrf2 could be a common denominator among cellular hormetic activators.[49] The importance of these transcription factors in the immune response is based on their participation in intracellular signaling pathways for activation of $\mathrm{T}$ lymphocytes,[9] whose adequate function is essential for defense against infection.

Ozone therapy is well tolerated and safe, with very few adverse events, since the rectal route is relatively noninvasive and painless and does not require use of needles or syringes.[40] This investigation shows similar safety and reactogenicity results to a 20-year followup study where ozone therapy was applied in patients with retinitis pigmentosa.[50] More intense and longlasting adverse events were identified In the CG, such as pain at the injection site, but these were predominantly local and less severe than previously described for Hebertrans.[51] Distension and reddening are caused by local inflammation and recruitment of inflammatory cells after several applications.

The study's monocentric nature is a limitation, since it prevents generalization of these findings as guidelines for other hospitals.

\section{CONCLUSIONS}

Our research results support ozone therapy as a suitable therapeutic option in treatment of IgA deficiency, because it produces antioxidant and immunomodulatory effects and is feasible, safe and minimally invasive.

\section{ACKNOWLEDGMENTS}

We thank Dr Maikel Roque Morgado, biostatistician for his support with data analysis.

\section{REFERENCES}

1. Raje N, Dinakar C. Overview of immunodeficiency disorders. Immunol Allergy Clin North Am [Internet]. 2015 Nov [cited 2017 Feb 21];35(4):599-623. Available from: https://www .ncbi.nlm.nih.gov/pmc/articles/PMC4600970/

2. Macías C, Sánchez M, Insua C, García MC, Hernández G, Arce A, et al. Tratamiento con inmunoglobulina $G$ subcutánea en enfermos con inmunodeficiencias primarias: resultados preliminares del estudio multicéntrico cubano. Rev Cubana Hematol Inmunol Hemoterapia [Internet]. 2016 [cited 2017 Feb 20];32(3):1-10. Available from: http://revhematologia.sld.cu/index.php/hih/ article/view/449/251. Spanish.

3. Kobrynski L, Waltenburg Powell R, Bowen S. Prevalence and morbidity of primary immunodeficiency diseases, United States 2001-2007.
J Clin Immunol [Internet]. 2014 [cited 2016 Mar 3];34(8):954-61. Available from: https://www .ncbi.nlm.nih.gov/pmc/articles/PMC4820073/

4. European Society for Immunodeficiencies [Internet]. Geneva: European Society for Immunodeficiencies; c2017. Registry. Diagnosis Criteria. New clinical diagnosis criteria for the ESID Registry; 2014 Mar [cited 2017 Feb 21]; [about 1 screen]. Available from: http://esid.org/Working -Parties/Registry/Diagnosis-criteria

5. Özcan C, Metin A, Erkoçoglu M, Kocabas CN Bronchial hyperreactivity in children with antibody deficiencies. Allergol Immunopathol (Madr) 2015 Jan-Feb;43(1):57-61.

6. Singh K, Chang C, Gershwin ME. IgA deficiency and autoimmunity. Autoimmun Rev [Internet] 2014 Feb [cited 2017 Jan 20];13(2):163-77.
Available from: http://linkinghub.elsevier.com/ retrieve/pii/S1568-9972(13)00180-8

7. Grupo de Trabajo de Inmunología Pediátrica. Guías de manejo: medidas generales de prevención de infecciones y quimioprofilaxis en las inmunodeficiencias primarias. Arch Argent Pediatr [Internet]. 2011 [cited 2016 Mar 3];109(3):26773. Available from: http://www.scielo.org.ar/pdf/ aap/v109n3/v109n3a19.pdf. Spanish.

8. García Martínez JM, Santos-Díez L, Dopazo L. Diagnóstico de las inmunodeficiencias primarias. Protoc Diagn Ter Pediatr [Internet]. 2013 [cited 2016 Feb 24];1:81-92. Available from: http:// www.aeped.es/sites/default/files/documentos/ 7-inmunodeficiencias_primarias_0.pdf. Spanish.

9. Abbas AK, Lichtman AH, Pillai S. Propiedades generales de las respuestas inmunitarias. In: 
Abbas AK, Lichtman AH, editors. Inmunología celular y molecular. 8th ed [Internet]. Barcelona: Elsevier; 2015 [cited 2017 Feb 21]. Available from: http://booksmedicos.me/inmunologia-celu lar-y-molecular-abbas-8a-edicion/. Spanish.

10. Bocci V. Does ozone therapy normalize the cellular redox balance? Implications for therapy of human immunodeficiency virus infection and several other diseases. Med Hypotheses [Internet]. 1996 Feb [cited 2017 Feb 21];46(2). Available from: http://www.ncbi.nlm.nih.gov/pub med/8692040

11. Martínez-Sánchez G. La ozonoterapia gana evidencia científica en el campo clínico. Rev Cubana Farm [Internet]. 2013 Apr 9 [cited 2016 Feb 24];47(1):1-4. Available from: http://bvs.sld.cu/ revistas/far/vol47 1 13/far01113.htm. Spanish.

12. Larini A, Bocci V. Effects of ozone on isolated peripheral blood mononuclear cells. Toxicol In Vitro [Internet]. 2005 Feb [cited 2016 Mar 3];19(1):5561. Available from: http://www.ozonoterapiafran cia.com.mx/_downloads/Publicaciones_Ozono/ Bocci\%202.pdf

13. Nazarina I, Menéndez S, Rivero J. Ozonoterapia en SIDA. Rev Cubana Invest Biomed [Internet]. 2005 Jan-Mar [cited 2017 Feb 21];24(1):69-71. Available from: http://bvs.sld.cu/revistas/ibi/ vol24 1 05/ibi09105.pdf. Spanish.

14. León Fernández OS, Viebahn-Haensler R, Cabreja GL, Espinosa IS, Matos YH, Roche LD, et al. Medical ozone increases methotrexate clinical response and improves cellular redox balance in patients with rheumatoid arthritis. Eur J Pharmacol [Internet]. 2016 Oct 15 [cited 2017 Feb 21];789:313-8. Available from: http://linkinghub elsevier.com/retrieve/pii/S0014-2999(16)30471-X

15. Díaz Luis J, Padrón Sardiñas G, Menéndez Cepero S, Macías Abraham C. [Immunomodulator effect of ozone therapy in children with deficiency in immunity mediated by phagocytes]. Mediciego [Internet]. 2012 [cited 2016 Jan 4];18(1). Available from: http://bvs.sld.cu/revistas/mciego/ vol18_01_2012/pdf/T9.pdf. Spanish.

16. Gazin IK, Istomin N. [Disturbed immune status and immunocorrective effect of ozone-assisted therapy in comparison with traditional treatment of patients with diabetes mellitus complicated by pyonecrotic lesions of the lower extremities]. Immunologiya. 2009;(1):60-1. Russian.

17. Asociación Española de Profesionales Médicos en Ozonoterapia (AEPROMO). Declaración de Madrid sobre ozonoterapia [Internet]. Madrid AEPROMO; 2012 [cited 2014 Nov 20]. Available from: http://files.sld.cu/rehabilitacion-fis/ files/2012/06/declaracion-de-madrid-actualiza da-30-julio-castellano-20102.pdf. Spanish.

18. Viebahn-Hänsler R, León Fernández OS, Fahmy Z. Ozone in medicine: the low-dose ozone concept-guidelines and treatment strategies. Ozone Sci Engineering. 2012;34(6):408-24.

19. Formulario Nacional de Medicamentos. Factor de Transferencia [Internet]. Havana: Centro para el Desarrollo de la Farmacoepidemiología (CU); 2017 [cited 2017 Dec 12]; [about 2 screens]. Available from: http://fnmedicamentos.sld.cu/index .php?P=FullRecord\&ID=380. Spanish

20. Ruiz Contreras J, González Granado LI. Pruebas de laboratorio en el diagnóstico de inmunodeficiencias primarias. An Pediatr Cont [Internet]. 2013 [cited 2016 Feb 24];11(5):282-90. Available from: https://www.clinicalkey.es/\#!/content/ journal/1-s2.0-S1696281813701495. Spanish.

21. Rozman C, Cardellach López F. Farreras Rozsman. Medicina Interna [Internet]. Barcelona: Elsevier; c2016 [cited 2017 Feb 21]. Chapter 338, Pruebas inmunológicas de interés diagnóstico; p. 2534-49. Available from: https://www.clinical key.es/\#!/content/book/3-s2.0-B978848086896 9003381. Spanish.
22. BIOPROCESS Online [Internet]. Pittsburg: BIOPREOCESS Online; c1996-2017. Product/ Service. Bioxytech LPO-586. Colorimetric assay for lipid peroxidation markers. Catalogue No. 941012. OXIS International, 1997; [cited 2016 Mar 3]; [about 1 screen]. Available from: https:// www.bioprocessonline.com/doc/bioxytech-lpo -586-colorimetric-assay-for-lipi-0001

23. Witko-Sarsat V, Friendlander M, Nguyen-Khoa T, Capeillère-Blandin C, Nguyen AT, Canteloup $S$, et al. Advanced oxidation protein products as novel mediators of inflammation and monocytes activation in chronic renal failure. J Immunol. 1998 Sep 1;161(5):2524-32.

24. Jiang ZY, Woollard AC, Wolff SP. Lipid hydroperoxide measurement by oxidation of $\mathrm{Fe} 2+$ in the presence of xylenol orange. Comparison with the TBA assay and an iodometric method. Lipids. 1991 Oct;26(10):853-6.

25. Marklund $S$, Marklund $G$. Involvement of the superoxide anion radical in the autoxidation of pyrogallol and a convenient assay for superoxide dismutase. Eur J Biochem. 1974 Sep 16;47(3):469-74.

26. Aebi $\mathrm{H}$. Catalase in vitro. Methods Enzymol. 1984;105:121-6.

27. Paglia DE, Valentine WN. Studies on the quantitative and qualitative characterization of erythrocyte glutathione peroxidase. J Lab Clin Med. 1967 Jul;70(1):158-69.

28. Sedlak J, Lindasy RH. Estimation of total protein bound and non-protein sulfhydryl group in tissue with Ellman's reagent. Anal Biochem. 1968 Oct 24;25(1):192-205.

29. Benzie IF, Strain JJ. The ferric reducing ability of plasma (FRAP) as a measure of antioxidant power: the FRAP assay. Anal Biochem. $1996 \mathrm{Jul}$ 15;239(1):70-6.

30. Ministry of Public Health (CU); Center for State Control of Medicines, Equipment and Medical Devices (CU). Regulación No. 45-2007. Requerimientos para la notificación y el reporte de eventos adversos graves e inesperados en los ensayos clínicos 2007 [Internet]. Havana: National Quality Control Center for Drugs, Medical Equipment and Devices (CU); 2007 [cited 2011 Jan]. 18 p. Available from: http:// www.cecmed.cu/sites/default/files/adjuntos/ Reglamentacion/reg_45-07_requerimientos para la notificacion_y el reporte de eventos _adversos_graves_e_inesperados_en_los_en sayos_clinicos.pdf. S̄panish.

31. World Medical Association. Declaración de Helsinki de la Asociación Médica Mundial. Principios éticos para las investigaciones médicas en seres humanos. Junio 1964 [Internet]. FerneyVoltaire: World Medical Association; 2017 Mar 21 [cited 2011 Jan 10]; [about 5 screens]. Available from: https://www.wma.net/es/policies-post/ declaracion-de-helsinki-de-la-amm-principios -eticos-para-las-investigaciones-medicas-en -seres-humanos/. Spanish.

32. Domínguez O, Giner MT, Alsina L, Martín MA, Lozano J, Plaza AM. Fenotipos clínicos asociados a la deficiencia selectiva de IgA: revisión de 330 casos y propuesta de un protocolo de seguimiento. An Pediatr [Internet]. 2012 [cited 2016 Feb 24];76(5):261-7. Available from: http://www.analesdepediatria.org/es/fenotipos -clinicos-asociados-deficiencia-selectiva/articulo/ S1695403311005522/. Spanish

33. De Oliveira-Serra FA, Mosca T, Santos de Menezes MC, Carvalho-Neves Forte W. Manifestaciones clínicas de la deficiencia de IgA. Rev Alerg Mex [Internet]. 2017 [cited 2017 Feb 24];64(1):34-9. Available from: http://revistaalergia.mx/ojs/index .php/ram/article/view/216/436. Spanish.

34. Urm SH, Yun HD, Fenta YA, Yoo KH, Abraham RS, Hagan J, et al. Asthma and risk of celective IgA deficiency or common variable immunodeficiency: a population-based casecontrol study. Mayo Clin Proc [Internet]. 2013 Aug [cited 2016 Jun 20];88(8):813-21. Available from: https://www.ncbi.nlm.nih.gov/pmc/articles/ pmid/23910409/

35. Rivas JJ, Brocardo GA, Kokron C, Rizzo LV, Kalil J, Barros MT. Caracterização imunofenotípica de linfócitos $B$ de memória na deficiência de $\operatorname{lgA}$ e imunodeficiência comum variável. Rev Bras Alergia Imunopatol [Internet]. 2010 Jan-Feb [cited 2016 Jun 20];33(1):23-31. Available from: http:// pesquisa.bvsalud.org/bvsecuador/resource/pt/ lil-563501. Portuguese.

36. Soheili $\mathrm{H}$, Abolhassani $\mathrm{H}$, Arandi N, Khazaei HA Shahinpour S, Hirbod-Mobarakeh A, et al. Evaluation of natural regulatory $T$ cells in subjects with selective IgA deficiency: from senior idea to novel opportunities. Int Arch Allergy Immunol. 2013;160(2):208-14.

37. Bezrodnik L, Di Giovanni D, Ginaca A, Krasovec $S$, Menard D, Carabajal $P$, et al. Evaluación clínica e inmunológica de 90 pacientes con deficiencia selectiva de inmunoglobulina A. Arch Argent Pediatr [Internet]. 2003 Sep-Oct [cited 2016 Mar 3];101(5):375-81. Available from: http://www.imbiomed.com/1/1/articulos.php?me thod=showDetail\&id articulo $=44150$ \&id seccion $=2737 \& i d \_$ejemplar $=4481 \& i d \_r e v i s t a=165$. Spanish.

38. Cruz Barrios MA, Rodríguez Montiel BN, Furones Mourelle JA, Martín de la Riva AD, Guerra Suárez LM, Páez Pérez AT. Patrones de prescripción del factor de transferencia en 11 hospitales de Ciudad de La Habana. Rev Cubana Salud Pública [Internet]. 2005 Dec [cited 2016 Mar 3];31(4):291-5. Available from: http://www .redalyc.org/articulo.oa?id=21418845004\&idp $=1$ \&cid=34574. Spanish

39. Inclán G. Respuesta clínica e inmunológica en pacientes con déficit de IgA después del tratamiento con factor de transferencia. Rev Cub Hematol Inmunol Hemoterapia. 1994;10:80-1. Spanish.

40. Martínez Sánchez G, Re L. Rectal administration and its application in ozone therapy. Intl J Ozone Therapy. 2012 Apr;11:41-9.

41. Mandzhgaladze NR, Kharebava ER, Didia TsG Ardzhevanishvili MD, Gudzhabidze MV, Chigiashvili TsN. [Influence of intravenous ozone treatment on the level of different specificity antibodies]. Georgian Med News [Internet]. 2006 Sep [cited 2017 Feb 21];(138):93-5. Available from: https://www.ncbi.nlm.nih.gov/ pubmed/17057311

42. Díaz Luis J, Macías Abraham C, Menéndez Cepero S. Efecto modulador de la ozonoterapia sobre la actividad del sistema inmune. Rev Cubana Hematol Inmunol Hemoterapia [Internet] 2013 [cited 2017 Feb 21];29(2). Available from http://www.revhematologia.sld.cu/index.php/hih/ article/view/27. Spanish

43. Smith AJ, Oertle J, Warren D, Prato D. Ozone Therapy: a critical physiological and diverse clinical evaluation with regard to immune modulation, anti-infectious properties, anti-cancer potential, and impact on anti-oxidant enzymes. Open $J$ Molecular Integr Physiol. 2015 Aug:5(3):37-48.

44. Sánchez Valle $V$, Méndez Sánchez N. Estrés oxidativo, antioxidantes y enfermedad. Rev Invest Med Sur Mex [Internet]. $2013 \mathrm{Jul}-S e p$ [cited 2016 Jul 24];20(3):161-8. Available from: http:// medicasur.org.mx/pdf-revista/RMS133-AR01 -PROTEGIDO.pdf. Spanish.

45. Elejalde Guerra Jl. Estrés oxidativo, enfermedades y tratamientos antioxidantes. An Med Interna [Internet]. 2001 Jun [cited 2017 Jan 5];18(6):326-35. Available from: http://scielo.isciii .es/scielo.php?script=sci arttext\&pid=S0212 -71992001000600010. Spanish. 
46. Pomier Suárez O, Gil del Valle L, Rodríguez Delgado F, Huetes L, Alerm González A, Bermúdez Alfonso $\mathrm{Y}$, et al. Indicadores de estrés oxidativo en pacientes afectados por $\mathrm{VIH} /$ sida con manifestaciones reumatológicas. Rev Cubana Farm. 2012 Jul-Sep;46(3):329-42. Spanish.

47. Hernández Rosales FA, Calunga Fernández JL, Turrent Figueras J, Menéndez Cepero S, Montenegro Perdomo A. Ozone therapy effects on biomarkers and lung function in asthma. Arch Med Res. 2005 Sep-Oct;36(5):549-54.

48. Corcho I, Hernández F, Reyes N, Carballo AL, Peña $O$, Reyes $T$, et al. [Changes in the immune system in inflammatory processes during the application of ozone therapy]. Rev CENIC Cienc Biol [Internet]. 1998 [cited 2017 Feb 21];29(3):203-5. Available from: http://amozon.org.mx/index.php/ blog/63-alergia-e-inmunologia/1171-changes-in -the-immune-system-in-inflammatory-processes -during-the-application-of-ozone-therapy. Spanish.

49. Bocci $\mathrm{V}$, Valacchi $\mathrm{G}$. Nrf2 activation as target to implement therapeutic treatments. Front Chem [Internet]. 2015 Feb 2 [cited 2016 Mar 3];3:4. Available from: https://www.ncbi.nlm.nih.gov/ pmc/articles/pmid/25699252/

50. Copello M, Menéndez S, Hernández F. Ozone therapy in retinitis pigmentosa patients: clinical evolution and oxidative stress behavior in retinitis pigmentosa patients treated with ozone therapy over 20 years. Ozone Sci Engineering. 2012 Dec 5;34(6):476-83.

51. Cruz Barrios MA. Reacciones adversas del factor de transferencia y características de su prescripción. La Habana, 2001-2010 [thesis] [Internet]. [Havana]: Dr Miguel Enríquez Medical School; 2014 [cited 2017 Feb 21]. Available from: http:// tesis.repo.sld.cu/863/1/Cruz Barrios.pdf. Spanish.

\section{THE AUTHORS}

Jacqueline Díaz-Luis (Corresponding author: jdiaz@hgm.cav.sld.cu), physician specializing in immunology, with a master's degree in infectious diseases, doctoral candidate. Associate professor and researcher Roberto Rodríguez Fernández Provincial General Teaching Hospital, Morón, Cuba.

Silvia Menéndez-Cepero, chemist. Senior researcher, National Scientific Research Center, Havana, Cuba.

Consuelo Macías-Abraham, physician specializing in immunology, with a doctorate in medical sciences. Full professor and senior researcher, Hematology and Immunology Institute, Havana, Cuba.

Lucía Fariñas-Rodríguez, biologist with a master's degree in anthropology. Adjunct professor and head, Oxidative Stress Laboratory, National Medical Genetics Center, Havana, Cuba.
Submitted: August 21, 2017

Approved for publication: December 18, 2017 Disclosures: None

\section{FOR A SAFER WORLD}

10th International Congress on Disaster Nursing and Disaster Management

6th International Firefighters Conference

July 2-8, 2018

Havana's International Convention Center
This conference brings together leading scholars to exchange experiences and research results on all aspects of disaster nursing and disaster management. It also provides a premier interdisciplinary platform for researchers, practitioners and educators to present and discuss recent innovations, trends, and concerns, as well as practical challenges encountered and solutions adopted.

Topics include, but are not limited to, climate change and disaster risk, disaster prevention, risk reduction for sustainable development, civil society and population preparedness, response planning, disaster response and post-disaster rehabilitation.

Languages: Spanish, English Information:wilmamj@palco.cu http://www.congresoDCcuba.com 